Brit. J. industr. Med., 1951, 8, 8.

\title{
BACTERIAL CONTAMINATION OF THE AIR IN BOOT AND SHOE FACTORIES
}

\author{
BY \\ ANN HIRCH \\ From the Air Hygiene Unit, Public Health Laboratory Service, Colindale
}

(RECEIVED FOR PUBLICATION NOVEMBER 29, 1950)

The total number of viable bacteria present in the air of occupied places has been advocated as a possible index of the degree of pollution of the air with pathogenic bacteria (Bourdillon, Lidwell, and Lovelock, 1948), but few attempts have been made to demonstrate a correlation of the bacterial count of such places with the sickness experience of the occupants. The analysis by Stewart and Hughes (1949) of the tuberculosis data from the boot and shoe factories in Northampton showed that tuberculosis was more prevalent in the large than in the small factories, and this has been confirmed in subsequent work (Stewart, personal communication, 1950). It therefore seemed worth making a bacteriological survey to find out whether the average levels of bacterial contamination of the air in these factories were similarly related to their size. This, in fact, has proved to be the case.

In all, 36 factories were visited, 15 in Northampton during the autumn of 1948 and 21 in Leicester during the spring of 1949 . The order in which the factories were visited was not strictly random, owing to a number of practical difficulties, but in general large and small factories were visited on alternate days; there was no other conscious selection of the order. One visit was paid to each factory and air samples were collected in each of the six main departments within the factory, the sampler being set up near the centre of the room.

\section{Methods}

Air-borne bacteria were collected with a slitsampler similar to that described by Bourdillon, Lidwell, and Thomas (1941). Two culture media were used : (1) nutrient agar containing 5\% horse serum, for estimation of the general bacterial count, the plates being counted after incubation for 24 hours at $37^{\circ} \mathrm{C}$. ; (2) a medium consisting of sucrose-serum-agar with crystal violet and potassium tellurite (Williams and Hirch, 1950), which is selective for streptococci and can be used to estimate the extent of respiratory pollution of the air.
Str. salivarius (Sherman, Niven, and Smiley, 1943), a common mouth streptococcus which gives readily distinguishable mucoid colonies on this medium, was used as the indicator organism. In Northampton, plates of serum agar and of the selective medium were exposed alternately, but in Leicester the sampler was modified so that the air was sampled on to the two media simultaneously.

In general, three serum-agar samples were collected in each room, a total volume of 15 to $18 \mathrm{cu}$. $\mathrm{ft}$. of air being sampled. In Northampton $20 \mathrm{cu}$. ft. of air were sampled on to the selective medium, but owing to the small numbers of streptococci present, this volume was insufficient, and in Leicester about $122 \mathrm{cu}$. $\mathrm{ft}$. were sampled. In each case the results from the three samples in one room have been added together and expressed as the average number of bacterial colonies per cu. ft. of air sampled.

Six factories were excluded from the statistical calculations because in five cases we had not all the information required, and in one case the bacterial counts differed so widely from the rest as to be suspect.

\section{Results}

Relation of Bacterial Count to Factory Size.-The bacterial counts were first tabulated in the five factory size groups, based on the total number of employees in the factory, used by Stewart and Hughes (1949). This showed clearly that there was an increase in count with increase in factory size (Table 1). As the factories in Northampton and Leicester showed the same general trend, the two cities have not been distinguished in the rest of the analyses.

Relation of Bacterial Count to Number of Workers and Floor Area per Worker.-From general impressions received while visiting the factories, it seemed possible that the higher bacterial counts in the larger factories might be attributable to a greater density of occupation. In order to test this idea a 
TABLE 1

MEAN GENERAL BACTERIAL COUNTS BY FACTORY SIZE GROUPS

\begin{tabular}{c|c|c|c|c|c}
\hline $\begin{array}{c}\text { Factory } \\
\text { Size- } \\
\text { Group }\end{array}$ & $\begin{array}{c}\text { Total No. } \\
\text { Workers on } \\
\text { Factory Roll }\end{array}$ & $\begin{array}{c}|c| \\
\text { No. Factories } \\
\text { in Group }\end{array}$ & $\begin{array}{c}\text { Mean Count } \\
\text { Colonies per } \\
\text { cu. ft. of Air }\end{array}$ & $\begin{array}{c}\text { Leicester } \\
\text { No. Factories } \\
\text { in Group }\end{array}$ & $\begin{array}{c}\text { Mean Count } \\
\text { Colonies per } \\
\text { cu. ft. of Air }\end{array}$ \\
\hline 5 & $>600$ & 5 & 44 & 1 & 39 \\
4 & $600-350$ & 3 & 36 & 2 & 27 \\
3 & $349-200$ & 2 & 29 & 3 & 31 \\
2 & $199-100$ & 2 & 22 & 3 & 24 \\
1 & $<100$ & 3 & 26 & 3 & 21 \\
\hline
\end{tabular}

TABLE 2

MEAN BACTERIAL COUNTS BY DEPARTMENTS AND FACTORY SIZE-GROUPS

\begin{tabular}{|c|c|c|c|c|c|c|c|c|c|c|c|c|c|c|c|c|c|c|c|c|c|c|}
\hline \multirow{3}{*}{ 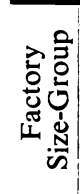 } & \multirow{3}{*}{ 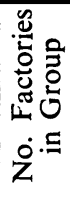 } & \multicolumn{18}{|c|}{ Department } & \multirow{2}{*}{\multicolumn{3}{|c|}{$\frac{\begin{array}{c}\text { All Depart- } \\
\text { ments }\end{array}}{\text { Means }}$}} \\
\hline & & \multicolumn{3}{|c|}{ Clicking } & \multicolumn{3}{|c|}{ Closing } & \multicolumn{3}{|c|}{ Roughstuff } & \multicolumn{3}{|c|}{ Shoe } & \multicolumn{3}{|c|}{ Finishing } & \multicolumn{3}{|c|}{ Making } & & & \\
\hline & & $C^{*}$ & A & W & $\mathrm{C}$ & A & W & $\mathrm{C}$ & A & W & $\mathrm{C}$ & A & W & $\mathrm{C}$ & A & $\mathrm{W}$ & $\mathrm{C}$ & A & W & $\mathrm{C}$ & A & W \\
\hline 5 & 6 & 69 & 71 & 90 & 44 & 50 & 152 & 41 & 132 & 56 & 41 & 84 & 60 & 35 & 83 & 86 & 32 & 84 & 116 & 44 & 84 & 93 \\
\hline 4 & 5 & 41 & 75 & 66 & 42 & 61 & 133 & 26 & 179 & 39 & 31 & 129 & 36 & 32 & 172 & 46 & 24 & 148 & 62 & 33 & 127 & 64 \\
\hline 3 & 6 & 39 & 83 & 39 & 34 & 55 & 84 & 23 & 250 & 18 & 26 & 157 & 25 & 29 & 118 & 28 & 30 & 103 & 44 & 30 & 128 & 40 \\
\hline 2 & 7 & 23 & 136 & 16 & 22 & 60 & 40 & 27 & 279 & 10 & 22 & 145 & 13 & 23 & 218 & 14 & 22 & 150 & 27 & 23 & 165 & 20 \\
\hline 1 & 6 & 26 & 140 & 8 & 22 & 65 & 21 & 27 & 260 & 5 & 23 & 237 & 10 & 24 & 223 & 10 & 23 & 154 & 14 & 24 & 180 & 11 \\
\hline $\begin{array}{l}\text { Weig } \\
\text { me }\end{array}$ & $\begin{array}{l}\text { hted } \\
\text { ans }\end{array}$ & 40 & 102 & 42 & 33 & 58 & 83 & 29 & 223 & 25 & 28 & 151 & 27 & 28 & 164 & 36 & 26 & 128 & 51 & 31 & 137 & 44 \\
\hline
\end{tabular}

more comprehensive table was drawn up (Table 2), and the data summarized in it were submitted to statistical analysis. The technical details of this analysis are set out in the appendix. In this case the "number of workers" refers to the actual number of people present in the room while the sample was being taken. There proved to be a positive correlation between the bacterial count and the number of workers, and a negative correlation between the count and the area per worker. There were also differences among the average counts for the various working departments. The problem was then to determine how far differences in floor area, or number of workers, accounted for the observed variation among the means, both between the different factories and the different departments within the factories.
Differences between Factories.-By a further analysis it was found that variations in area and number of workers could account for about half the variance due to differences between the mean bacterial counts from the various factories. Elimination of these two factors, however, still left significant variation, which was doubtless due to the many differences in age, structure, degree of cleanliness, and ventilation methods among them. An additional factor which may have been responsible, both for differences between individual factories, and between departments in any one factory, was that in some places the departments were in completely separate rooms, while in others (particularly some of the more modern factories), some or all of them were in one large workshop, with or without separation by partitions. This factor has 
not been considered in the present analysis, because when the departmental counts were tabulated by factory size for separate rooms, partitioned rooms, and those completely open to one or more of the other departments, the same general trend of a decrease in bacterial count with decreasing factory size was apparent. In addition correlation coefficients, calculated from the counts of the making and finishing departments, these two departments being frequently in adjoining rooms, (1) where they shared a common room and (2) where they were in separate rooms, were not significantly different.

Differences between Departments. - Examination of Table 2 shows differences among the mean counts for the various departments and these were found to be statistically significant. The clicking and closing rooms apparently had a higher average count than other departments, and this was particularly true of the larger factories. In order to examine these interdepartmental differences more fully the observed mean values were corrected to allow for the effect of differences in the average area per worker and number of workers present (see Appendix). On this new basis the departments could be divided into two groups (Table 3), the

TABLE 3

CORRECTED MEAN BACTERIAL COUNTS BY DEPARTMENTS

\begin{tabular}{l|c}
\hline Department & $\begin{array}{l}\text { Mean General Count } \\
\text { (Colonies per cu. ft.) }\end{array}$ \\
\hline Clicking & 35 \\
\hline Roughstuff & 31 \\
Finishing & 28 \\
Shoe room & 28 \\
Closing & 27 \\
Making & 25 \\
\hline
\end{tabular}

clicking department having a significantly higher mean count than any of the other five, among which there was now no significant difference. In the clicking department the workers are engaged in cutting out the leather for the uppers of the shoes, and this fact may be one possible explanation for the relatively high count in this department as the work involves a certain amount of movement of hides and many small rapid movements by the workers, which might well be expected to liberate bacteria from clothing (Duguid and Wallace, 1948). In the roughstuff department, where the bacterial count also tended to be high, there is considerable movement of the large heavy hides used for the soles of the shoes. The finishing room is said, by the workers in this industry, to be one of the dustiest departments, as a quantity of fine leather dust is produced during the smoothing of the soles. Accumulation of this dust is, however, usually prevented as most of the machines in this department are fitted with extractor fans. The work in the closing room is mainly sedentary so that there is not the same opportunity for liberation of dust and bacteria from the floor dust or clothing of the operatives. A possible explanation of the rather low count in the making departments is the presence of large machines, some of which expose an oily surface to which any floating dust particles would tend to adhere ; in some factories the floor in this department looks slightly oily.

Str. salivarius.-The number of Str. salivarius found was very small, and in Northampton, due to the small volume of air sampled, no weight can be attached to the counts obtained. When the average counts for 18 of the Leicester factories (those for which counts were available from all six departments) were arranged in decreasing order of factory size and divided into three size groups, the average for the large factories was found to be $0 \cdot 14$, the intermediate ones $0 \cdot 11$, and the smallest 0.09 colonies per $\mathrm{cu}$. $\mathrm{ft}$. of air. The highest mean counts by departments, 0.18 and 0.12 per cu. $\mathrm{ft}$., were found in the making and clicking rooms. In the making room the higher count was possibly due to the presence of noisy machinery, which causes the workers to shout and so disperse more of these organisms.

\section{Discussion}

Although this was no more than a preliminary survey, the consistency of the results seemed to justify fairly full analysis for the information they may give on the factors affecting the general bacterial count. As was to be expected, an increased density of occupation led to an increase in the count, but so also did an increase in the total number of workers in a room even when the density effect was excluded. Increase in the number of workers naturally reflected an increase in the size of the rooms, which made the correlated increase in count even more interesting since the larger workrooms were often in the more modern buildings. One possible explanation of the higher count is that it is more difficult to ventilate large rooms than small, but unfortunately there are at present no convenient methods of estimating the ventilation rate in spaces of the size of the factory workrooms, so that it is difficult to verify this suggestion. Owing to practical difficulties we were unable to estimate the height of the room and so the volume per worker, and we cannot be certain what relation the volume bears to floor area. Another possible explanation is that some persons 
may disperse a great many more bacteria than others, and in such a case the fact that there are more workers in a room will mean that there is more chance of including such a heavy disperser.

In advocating a general bacterial count as an indication of the adequacy of ventilation in a particular space, Bourdillon and others (1948) suggested the level of 50 bacteria-carrying particles per cu. $\mathrm{ft}$. of air as a maximum " to be considered satisfactory in any ordinary occupied space". It is of interest that this figure was exceeded in only 17 of the 126 rooms visited. An index of this sort, to be used to reveal differences in ventilation, presupposes a uniform dissemination of bacteria in the different places. Ordinarily this does not obtain, but in a set of factories where the work being done is the same, differences in count between otherwise comparable factories may well be of some significance as a possible reflection of differences in ventilation and general dustiness, and in such circumstances a generai bacterial count could be regarded as of value in indicating hazardous deficiencies in ventilation and the like.

Considerably more work will be needed to define the relationship between the levels of bacterial pollution of air and tuberculosis incidence, but the fact that the two indices run parallel within this group of factories seems to be a point of great interest. None of the factories has sufficient records for analysis of the prevalence of minor respiratory sickness. This aspect of the problem has therefore had to be studied elsewhere.

\section{Summary}

The general bacterial count of the air was estimated in each of the six main working departments of 36 boot and shoe factories.

The mean bacterial count was found to increase with increase in the number of workers in the room, i.e. with increase in factory size; and there was also a significant, but less marked, decrease in the count with an increase in the area per worker.

There was a variation in the mean count between the different departments, the count in the clicking rooms being significantly higher than that in the other departments.

This work was begun as a result of discussions between Dr. Alice Stewart and the Medical Research Council's Air Hygiene Committee, and it was greatly assisted throughout by support and advice from Dr. Stewart and her colleagues. It could not have been carried out without a great amount of help from the managements of the factories visited and from Dr. L. Hoyle and Dr. E. H. Gillespie, the Directors of the Northampton and Leicester Public Health Laboratories, to all of whom thanks are due.

\section{REFERENCES}

Bourdillon, R. B., Lidwell, O. M., and Lovelock, J. E. (1948). Spec. Rep. Ser. med. Res. Coun., Lond., No. 262.

- J and Thomas, J. C. (1941). J. Hyg., Camb., 41, 197.

, P ancet, 2,845 .

Sherman, J. M., Niven, C. F., Jr., and Smiley, K. L. (1943). J. Bact., $45,249$.

Stewart, A., and Hughes, J. P. W. (1949). Brit. med. J., 1, 926.

Williams, R. E. O., and Hirch, A. (1950). J. Hyg., Camb. In the press. 


\section{A $P$ P $P$ E $\quad$ N D I X}

BY

\section{R. E. O. WILLIAMS}

From the Hygiene Unit, Public Health Laboratory Service, Colindale

The results available for all six departments in each of 30 different factories comprised (1) total bacterial count in colonies per cu. ft., (2) approximate area per worker (sq. ft.), and (3) number of workers present. In the following analysis the square root of the bacterial count has been used rather than the count itself.

We wished to discover whether, in this set of observations, there were significant differences between the bacterial counts in factories of different sizes, or between the different departments within the factories, and whether any differences observed in the counts could be attributed to variation either in the floor area per worker or in the number of workers in the department.

In the first place the results from the 180 units were tested for correlation of the bacterial counts $(c=\sqrt{ }$ count $)$ with area per worker $(a)$ and number of workers $(w)$. The results of this analysis were as follows :-

Partial correlation

$$
\text { coefficients : } r_{\text {caw }}=-0.387, P<0.01
$$$$
r_{c v . a}=+0.422, P<0.01
$$

Regression equation : $\hat{c}=5.349-0.003 a+0.009 w$.

Standard partial regression coefficients (Snedecor, 1948) : $b_{\text {caw. }}^{\prime}=-0.268$

$$
b_{c w . a}^{\prime}=+0.323
$$

Multiple correlation coefficient : $R=0.490$

It is evident therefore that the count was significantly correlated with both area and number of workers, and that an increase in the number of workers increased the count to a greater extent than increase in area per worker decreased it.

Secondly the results were examined by analysis

TABle 4 .

ANALYSIS OF VARIANCE OF SQUARE ROOT OF BACTERIAL COUNT

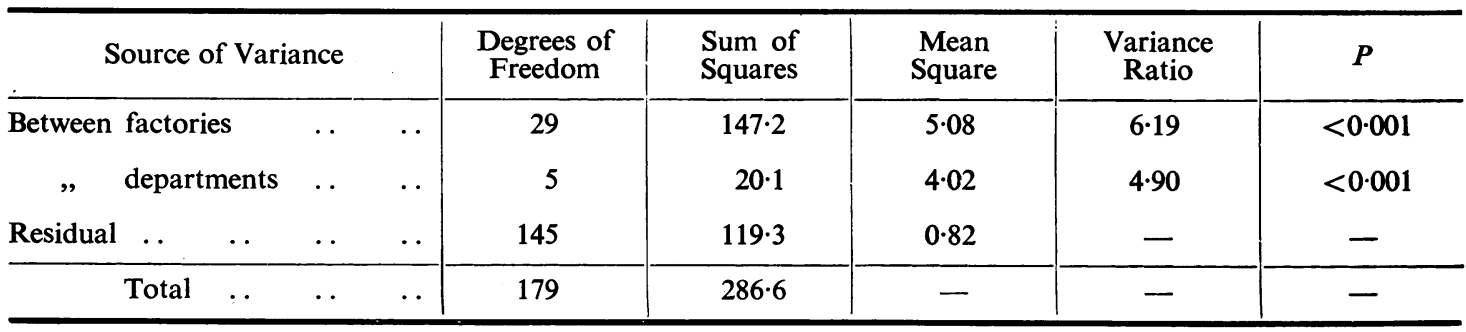

TABLE 5

\begin{tabular}{|c|c|c|c|c|c|c|c|c|c|}
\hline Source of Variance & & $\begin{array}{l}\text { Sum of } \\
\text { Squares }\end{array}$ & D.F. & $R^{2}$ & $\begin{array}{l}\text { Corrected } \\
\text { Sum of } \\
\text { Squares }\end{array}$ & D.F. & $\begin{array}{l}\text { Mean } \\
\text { Square }\end{array}$ & $\begin{array}{c}\text { Variance } \\
\text { Ratio }\end{array}$ & $P$ \\
\hline Between factories .. & .. & $147 \cdot 2$ & 29 & - & $76 \cdot 53$ & 29 & $2 \cdot 64$ & $3 \cdot 33$ & $<0.001$ \\
\hline Residual .. & $\cdots$ & $119 \cdot 3$ & 145 & 0.051 & $113 \cdot 22$ & 143 & $0 \cdot 79$ & - & - \\
\hline Factories + residual & $\cdots$ & $266 \cdot 5$ & 174 & $0 \cdot 288$ & $189 \cdot 75$ & 172 & - & - & - \\
\hline Between departments & .. & $20 \cdot 1$ & 5 & - & $17 \cdot 40$ & 5 & 3.48 & $4 \cdot 41$ & $<0.001$ \\
\hline Residual $\quad \ldots \quad \ldots$ & . & $119 \cdot 3$ & 145 & 0.051 & $113 \cdot 22$ & 143 & 0.79 & - & - \\
\hline Departments + residual & $\cdots$ & $139 \cdot 4$ & 150 & 0.063 & $130 \cdot 62$ & 148 & - & - & - \\
\hline
\end{tabular}

COVARIANCE ANALYSIS OF SQUARE ROOT OF BACTERIAL COUNT 
of variance (Table 4). Both the between-factories and the between-departments mean squares were significantly greater than the residual mean square, so that there was significant heterogeneity within both these two groupings.

To test whether the differences between the factories could be attributed to variation in area per worker or in number of workers, a covariance analysis was carried out (Table 5). The elimination of the effect of the regression from the analysis of variance left significant heterogeneity among both factories and departments. It is clear therefore that, although the allowance for the regression reduced the between-factories mean square by about a half, the corrected mean square was still significantly greater than the residual mean square, so that this regression did not account for all the difference between the factories.

TABLE 6

CORRECTED MEAN VALUES OF THE SQUARE ROOT OF THE BACTERIAL COUNT FOR DEPARTMENTS

\begin{tabular}{|c|c|c|c|c|c|}
\hline Department & $\bar{c}$ & $\bar{a}$ & $\bar{w}$ & $\overline{c^{\prime}}$ & Differences \\
\hline Clicking & 6.026 & $102 \cdot 6$ & $42 \cdot 3$ & 5.952 & \\
\hline Roughstuff . . & $5 \cdot 265$ & $223 \cdot 2$ & $24 \cdot 6$ & $5 \cdot 562$ & 0.253 \\
\hline Shoe & $5 \cdot 198$ & $150 \cdot 7$ & $27 \cdot 6$ & $5 \cdot 310$ & \\
\hline Finishing & $5 \cdot 193$ & $163 \cdot 7$ & $35 \cdot 8$ & $5 \cdot 295$ & 0.172 \\
\hline Closing & $5 \cdot 530$ & $57 \cdot 8$ & $82 \cdot 3$ & $5 \cdot 153$ & 0.220 \\
\hline Making & 4.992 & $127 \cdot 6$ & $51 \cdot 2$ & 4.933 & \\
\hline
\end{tabular}

The source of the differences between departments was further investigated by the method suggested by Tukey (1949). The mean bacterial counts for each department were first transformed to corrected means on the basis of the regression equation :

$$
\overline{c^{\prime}}=\bar{c}+b_{c a \cdot w \cdot}(\overline{\bar{a}}-\bar{a})+b_{\iota w \cdot a \cdot} \cdot(\overline{\bar{w}}-\bar{w})
$$

where $\bar{c}^{\prime}=$ the corrected department mean, $\bar{c}=$ the observed department mean, $\bar{a}$ and $a=$ the observed grand mean of areas and the department mean area respectively, and $\bar{w}$ and $\bar{w}=$ the corresponding mean numbers of workers; $b_{c a . w}$ and $b_{c w . a}$ are the partial regression coefficients of count on area and number of workers respectively derived from the " residual" line of the covariance analysis. The results obtained are shown in Table 6, in which the departments are arranged in descending order of their corrected mean bacterial counts.

According to Tukey any difference between successive means can be considered significant if it exceeds the value of $t_{[5 \%]}$. (2 $\left.2^{\frac{1}{2}}\right) . s_{m}$. The $5 \%$ level of $t$ for 60 degrees of freedom is 2.00 , and in the present case $s_{m}$ is estimated as $(0 \cdot 79 / 30)^{\frac{1}{2}}=0 \cdot 162$. The least significant difference is therefore $2.0 \times$ $1.414 \times 0.162=0.458$. No difference exceeds this value.

However by Tukey's second test the mean for the clicking room $(5 \cdot 952)$ is found to differ excessively from the grand mean 5.368 since

$$
\frac{\frac{5.952-5.368}{0 \cdot 162}-\frac{6}{5} \log _{10} 6}{3(1 / 4+1 / 145)}=3.46
$$

and this value is greater than the $1 \%$ level of the normal deviate. By the same test there is no significant difference among the remaining nive means, and the variance ratio for them $(2.03)$ is also not significant. We may therefore conclude that the clicking department mean count differs significantly from the rest, which show no differences among themselves.

I am indebted to Mr. P. Armitage, of the M.R.C. Statistical Research Unit, for much helpful advice on this analysis.

\section{REFERENCES}

Snedecor, G. W. (1948). Statistical Methods. Iowa State Collegc Press.

Tukey, J. W. (1949). Biometrics, 5, 99. 